Page $103-124$

\title{
THE NATURE OF FOOD COMMODITY PRICES VOLATILITY IN DRIVING INFLATION AND POLICY
}

\author{
Nurliza \\ University of Tanjungpura \\ nurliza.spmm@gmail.com
}

\begin{abstract}
The objective of research is to analyze the volatility effect of food commodity prices and whether surging food commodity prices have spilled over into food inflation and total inflation with time series data through Box-Jenkins method for 12 food commodity prices. The results have proved that only beef price had high volatility effects and have asymmetric effect. While, soybeans, cooking oil, and food are vulnerable but did not have volatility effects. The change in food commodity prices are significant drive the inflation in the long-term although in the short-term insignificant. The government needs to overcome the full transmission effect of an exogenous shock and to introduce economic reform through investment, infrastructure, and markets for corn and egg for food inflation; eggs and peanuts for total inflation. Besides, strong second-round effects of higher commodity prices on inflation have generally been absent converged to core inflation.
\end{abstract}

Keywords: food commodity prices, inflation, policy, volatility

\begin{abstract}
Abstrak
Tujuan penelitian adalah menganalisis pengaruh volatilitas harga komoditas pangan dan lonjakan harga terhadap terjadinya inflasi pangan dan inflasi total dengan data time series melalui metode BoxJenkins terhadap harga 12 komoditas makanan. Hasil penelitian menunjukkan bahwa hanya harga daging sapi yang memiliki efek volatilitas tinggi dan efek asimetris. Sementara itu, kedelai, minyak goreng, dan makanan bersifat rentan tetapi tidak memiliki efek volatilitas. Perubahan harga komoditas pangan yang secara signifikan mempengaruhi inflasi jangka panjang meskipun tidak dalam jangka pendek. Pemerintah perlu mengatasi efek transmisi dari kejutan eksogen dan memperkenalkan reformasi ekonomi melalui investasi, infrastruktur, dan pasar terutama untuk komoditas jagung dan telur terkait inflasi pangan; telur dan kacang terkait total inflasi. Efek putaran kedua yang kuat dari harga komoditas yang lebih tinggi dari inflasi umumnya tidak terfokus menjadi inflasi inti.
\end{abstract}

Kata Kunci: harga komoditas pangan, inflasi, kebijakan, volatilitas

Received: December 29, 2016; Revised: February 9, 2017; Approved: February 15, 2017. 
The Nature of Food Commodity...

Nurliza

\section{INTRODUCTION}

High inflation has been one of the challenges facing developing economies since the start of the transition process like Indonesia. Several factors may be driving inflation. Recent commodity price shocks have contributed due to the large share of food in the consumption basket. On average, food price inflation had led to an increase in headline inflation. At the same time, robust economic growth over the past years is likely to have intensified price pressure. In addition, other forces, including catching up and transition related factors - such as price deregulation, subsidy reduction, rising demand due to higher income-may be also key determinants of inflation in developing countries. Against this background, what is the outlook for inflation in the near future, as most food commodity markets are volatile, and volatility itself fluctuates over time, oil prices reverse the sharp gains of the past year, economic activity slows down in the wake of the financial crisis, and the convergence process proceeds and the implications for inflation.

Food is a substantial commodity for human life. People need food's commodity at affordable prices. The volatility of food's commodity prices can make people suffered. Because of that, government should create a policy to keep the food price stability. The instability in food prices commodity can lead a disruption in economy. The volatility in food prices can make a domino effect on others commodities. Others commodities will also rises according to the food prices commodity volatility. Sholehah (2016) found that there is a relationship between price volatility on food commodities inflation in Malang. Santoso (20II) find that the inflation behavior of food commodities in Indonesia is good enough. Although there is a high price volatility.

This paper tries to address these issues, by assessed the volatility effect of food commodity prices. The paper also studies whether surging food commodity prices have spilled over into the food inflation and total inflation. Concerns about secondround effects remain relevant even as commodity prices moderate, because domestic price pressures may persist for some time as a result of the continuing feed-through of past food price increases. Furthermore, managing the risks posed by commodity especially food commodity prices volatility requires a combination of mutually consistent policies with specific characteristics and circumstances is needed; some general principles can be discerned regard managing food commodity prices volatility itself. 


\section{METHOD}

Estimation uses time series data i.e. monthly for January, 2010 to December, 2014, for 12 food commodity prices that traded at traditional market in Pontianak City, West Kalimantan, such as rice, cooking oil, sugar, corn, peanuts, soybeans, eggs, red pepper, and red onion. The paper is organized as follows. In section one; we estimate the volatility of food commodity prices, food inflation, and total inflation. Price are endogenous, and can depend directly or indirectly on volatility, as well as on the exogenous variables, predict volatility because only the spot price and convenience yield are significant predictors of volatility. This could simply reflect the fact that past values of the spot price affect past values of volatility, which in turn affect its current value (Pindyck, 2004).

Box-Jenkins method i.e. Autoregressive Integrated Moving Average model (ARIMA/Box-Jenkins) which are consist of Autoregressive (AR), Moving Average (MA), Autoregressive-Moving Average (ARMA), and Autoregressive Integrated Moving Average (ARIMA) is used to build the time-series model with the spot price volatility. Then, the behavior of high volatility data was estimated by Heteroscedasticity Conditional Autoregressive models $(\mathrm{ARCH})$ and Generalized Autoregressive Conditional Heterokedasticity models $(\mathrm{GARCH})$, as well as some of its variants, i.e. ARCH-Mean (ARCH-M), Threshold ARCH (TARCH) and Exponential GARCH $(E G A R C H)$. This Autoregressive Conditional Heteroscedasticity $(\mathrm{ARCH})$ model became known as the Generalized Autoregressive Conditional Heteroscedasticity $(\mathrm{GARCH})$ model tends to work better for modeling high frequency time series data as suggested by most researchers (Regnard \& Zakoïan 20II; Hassan \& Regassa, 20I2) and the usefulness of $A R C H$ and $G A R C H$ models in suggesting that $A R C H$ models are very suitable for studying volatility of time series data (Engle, 2002). Next step was to measure the volatility effects or $\mathrm{ARCH}$ effect in residual, which was identified by heterokedasticity-test. When the best model is selected for each commodity, the error normality-test with Jarque-Berra model was used for model evaluation, accordingly the error of data is not normal then it is necessary to re-estimate to obtain the valid conclusions with asymptotically and the parameters remain consistent by heterokedasticity consistent covariace-test.

In section two, we analyze the causality between the food commodity prices and food inflation, also food commodity prices and total inflation. Standard approaches 
The Nature of Food Commodity...

Nurliza

to evaluating the impact of commodity events on domestic markets typically focus on the pass-through which have also been widely employed in estimating the effect of the prices on inflation (Vavra \& Goodwin, 2005; Blanchard \& Gali, 2007; IMF, 2008; Ferrucci et.al., 2012; Bakucs et.al., 2014). All of these sections will provide a framework to determine whether the food prices have driven inflation for policy action to anticipate it. The least squares method was used to determine the causality model by regression cointegrated and ECM models, i.e. food prices on food inflation and total inflation. The stationary-test was used first to avoid spurious regression or hypotheses become valid (t-test and F-test).

\section{RESULT AND DISCUSSION \\ Volatility Effect on Food Commodity Prices, Food Inflation, and Total Inflation}

The volatility of food commodity prices, food inflation, and total inflation were estimated by the past values of the spot price that affect past values of volatility, which in turn affect its current value. First, the stationary-test should be done to avoid spurious regression or hypotheses becomes valid through ADF-test and PP-test. Then, Box-Jenkins method is used to estimate the data behavior i.e. Autoregressive (AR), Moving Average (MA), Autoregressive-Moving Average (ARMA), and Autoregressive Integrated Moving Average (ARIMA) with two steps. First, an ARIMA model was indentified stationary on $\mathrm{I}^{\text {st }}$ difference data based on corelogram stationary and unit root-test. ARIMA models are determined by the lag of ACF and PACF spike patterns, which are significant. Second, the best model is selected base on some considerations, i.e. the coefficient of determination (R-Squared) is the largest, Akaike Information Criteria (AIC) or Schwartz Criterion (SC) is the smallest, and many of coefficients are significants.

Furthermore, the volatility effects or ARCH effect in residual was identified by heterokedasticity-test (ARCH-LM-test) base on the value of $\chi 2$-stat (if obs $*$ R-squared significant, its mean there is $\mathrm{ARCH}$ effect). The result proved that some price of food commodities were high volatility, i.e. beef, sugar, and corn. However, for the price of sugar the conclusion become asymptotically invalid and the parameters was not consistent. Next, the estimation and simulation of some variance model were conducted by embedding the $\mathrm{ARCH}$ effect and select the best model for the high 
volatility of data behavior. High volatility of data indicated a stage where the data fluctuation is relatively high, followed by a low fluctuation and return to high fluctuation which effect the error variance data is not constant (heterocedasticity) and the conclusions of model is spurious. The evaluation of high volatility of data behavior were estimated by Heteroscedasticity Conditional Autoregressive models $(A R C H)$ and Generalized Autoregressive Conditional Heterokedasticity models (GARCH), as well as some of its variants, i.e. ARCH-Mean (ARCH-M), Threshold ARCH (TARCH) and Exponential GARCH (EGARCH). After the best model was selected, error normalitytest with Jarque-Berra model was used for evaluation, if the error of data is not normal or Jarque-Berra statistic is significant then it is necessary to re-estimate by heterocedasticity consistent covariance-test to acquire the asymptotically valid conclusions and the parameters remain consistent.

The result proved that the residuals Jarque-Bera-test was normally distributed for garlic, rice, chicken meat, corn, peanutss, eggs, and total inflation in the previous month period (lag). However, some food commodity prices, i.e. red onion, red pepper, beef, sugar, soybean, cooking oil, and food inflation proved that the residual JarqueBera-test was not normal, so heterokedastisity consistent covariant-test was used for them. However, the results have shown that the residual heterokedastisity consistent covariant remained insignificant, so the conclusion becomes asymptotically invalid and parameters are not consistent for red onion, red pepper, and sugar. While, beef, soybeans, cooking oil, and food inflation indicated that there was an asymmetric effect that suggesting domestic price are vulnerable.

The results of volatility effect analysis found strong evidence that the price of beef had high volatility effect and an asymmetric effect. While, the price of corn had volatility effect, but normally distributed. Volatility effect reflects that market crashes and sudden, relatively large changes in price are more likely than it is commonly believed. It implies that, there is an unreciprocal relationship between rise and fall of commodity prices at various stages in the marketing chain. This stems from the fact that there is so tightly interconnected and that on the market there are few entities that can exert much influence on the price, such as the importance of specific products, independently of the concentration of that basket on one or two commodities, business cycles, changing weather patterns, conflict in producing, price 
The Nature of Food Commodity...

Nurliza

speculation, and farm subsidies.

While, normal distribution would imply, the time price change as the effects of myriad individual investors' decisions result in a pretty narrow range of change. Yet there are times (usually with relatively high volume) when those influential entities present the same attitude towards market situation and make the same decisions, which push the market in one direction significantly. Meanwhile, contrary to normally distributed, asymmetric effect which refers to pricing phenomenon occurring when downstream prices react in a different manner to upstream price changes (Akpan et.al., 2016).

Then, the price of soybeans, cooking oil, and food inflation did not have volatility effect, but there was an asymmetric effect. A possible implication of asymmetric price transmission is that consumers are not benefiting from price reduction at the producers' level, or producers might not benefit from price increase at the retail level (Meyer \& CramonTaubadel, 2004). Under asymmetric price transmission, the distribution of agents welfare across levels of market chain following shocks or government interventions will be altered relative to the case of symmetric price transmission. On the other hand, symmetric price adjustment has being noted to help optimize resource use; increase farm incomes; signal the degree of competitiveness, widen commodity markets and encourage value addition as well as create employment (Acquah \& Rebecca, 2012; Akpan, et.al., 2016).

The consequence of asymmetric effect received a considerable attention in economic literature because of two reasons. Firstly, its presence is not in line with predictions of the canonical economic theory (e.g. perfect competition and monopoly), which expect that under some regularity assumptions (such as non-kinked, convex/concave demand function) downstream responses to upstream changes should be symmetric in terms of absolute size and timing. Secondly, asymmetric effect is important from the welfare point of view, which implies welfare redistribution from agents downstream to agents upstream; it has serious political and social consequences (Meyer \& Cramon-Taubadel, 2004), and standard economic theory that does not account for this situation must be incorrect (Peltzman, 2000). Such an asymmetric effect may result from costly factor reallocation, uncertainty, and an asymmetric policy response. 
The volatility effect of food commodity prices could affects resource industry performance through investment supply and, to a lesser extent, investment demand decisions, and resource industry performance affects macroeconomic performance through the generation of resource rents. The more specialized an economy is in resource intensive activities, the more volatile their commodity prices are, the more sensitive their investment supply responses are, and the more important resource rents are to the aggregate economy, the stronger the connection will be linking price volatility to poor growth performance.

The heightened volatility was also encouraged by some factors, i.e. the broad fundamentals, being underpinned by strong demand and supply constraints which related to the fact that many commodities are traded in transparent; the heterogeneity in price behavior between commodities; the increase in the correlation between commodity prices and other financial prices; the increase in the price correlation between commodities that make up the major commodity indices-and which are thus invested in by index funds-is mixed; there has not been a large increase in commodity inventories that we would expect to accompany speculation-driven price rises (Dwyer et.al., 20I I).

Changes in volatility that suggesting the price vulnerable, making it more volatile and hence making the investment more risky and uncertainty, which discourages investment. Its can affect food commodity market by directly affecting the marginal value of storage, and by affecting a component of the total marginal cost of production, the opportunity cost of producing the commodity now rather than waiting for more price information (Pindyck, 2004; Keay, 2010). Commodity price, and price volatility hikes have been shown to be economically detrimental as they could impede the economic growth in poor countries (Jacks et.al., 20II), increase poverty (Von Braun \& Tedesse, 2012), create worldwide unrest (protests and riots), and threaten political stability. Furthurmore, the impact of high volatility on farmers are intra-annual volatility, inter-annual volatility, and farmer's struggle to plan their economic activities; on farmers organizations are the struggle with managing price, undermine group/collective dynamics; and on producers are mostly negative (Davis, 20I I).

While price signals play an important role in boosting future supply and allocating existing supply, volatility in prices can hinder this process by generating 
The Nature of Food Commodity...

Nurliza

uncertainty about future price levels. The recent increase in commodity price volatility because in the short-term both global supply, such as adverse weather patterns, low inventory levels, increasing scarcity of land and water, a history of under investment in productive capacity, weather-related disturbances-droughts, floods; and demand for commodities are relatively price inelastic even though the above mentioned arguments of supply and demand are insufficient to explain the full extent of the increases and volatility in food prices (Schutter, 2010; Rayner et.al., 201 I). Commodity price volatility was generally higher given that the commodity price booms. Volatility subsequently declined was at the period during which the world economy experienced high, stable and non-inflationary rates of economic growth.

The high volatility of food commodity prices needs to be anticipated for several reasons. First, high food prices present incentives for increased long-term investment, which can contribute to improved food security in the longer term. It is essential to build upon this short-term supply response with increased investment, including initiatives that target smallholder farmers and help them to access market. Second, Large short-term price changes can have long-term impacts on development. Changes in income due to price swings can reduce the consumption, leading to a permanent reduction of their future earning capacity, increasing the likelihood of future poverty and thus slowing the economic development process. Third, the price volatility makes both smallholder farmers and poor consumers increasingly vulnerable to poverty because the food represents a large share of farmer income and the budget of poor consumers; large price changes have large effects on real incomes. Thus, even short episodes of high prices for consumers or low prices for farmers can cause productive assets-land and livestock, leading to potential poverty traps. In addition, smallholder farmers are less likely to invest in measures to raise productivity when price changes are unpredictable.

Instead, a number of signs indicate that a significant portion of the price spike was due to the emergence of a speculative bubble. The changes in food prices reflected not so much movements in the supply and/or demand of food, but were driven to a significant extent by speculation that greatly exceeded the liquidity needs of commodity markets to execute the trades of commodity users. Another form of speculation is based simply on market momentum. This has been described as "herding 
behavior in times of strong (usually upward) price trends, which in developed and easily accessible markets can result in the emergence of speculative bubbles. Far from providing a stabilizing hand, such speculation tends to increase price volatility and different kinds of speculation in different markets combined to create the food price crisis, and that no one category of market conduct was singly responsible (Schutter, 2010). While, some traditional speculation in agricultural commodities markets is based on market fundamentals-above all on the demand and supply for any particular commodity (EU-Commission, 2008).

In regarding the commodity prices, Altissimo et.al. (2005) shows that the frequency of price changes is somewhat lower which implies that prices in the consumer sector are substantially stickier. Price stickiness can arise due to various reasons. On the one hand, in a stable macroeconomic environment, where agents trust in price stability, there is less need to change prices. On the other hand, there might be structural inefficiencies that can prevent firms from changing prices.

Therefore, a key element in managing price volatility in food markets is sustained investment to increase the productivity and resilience of food production (FAO et al., 20II). However, investment in agriculture remains critical to sustainable long-term food security. Such investment will improve the competitiveness of domestic production, increase farmers' profits and make food more affordable for the poor. These investments should consider the rights of existing users of land and related natural resources, benefit local communities, promote food security and not cause undue harm to the environment (FAO, 20I I). So, there are some measures to ensure its success as follows: (i) policy response for food insecurity are safety nets and food reserves to increased productivity enhancing investments to address vulnerability through increased incomes, etc and increases resilience to shocks with systems and supply chain finance, commodity exchanges and price risk management, and market information system all meant to expand participation of farmers in local and regional, markets enhance market access and increase farmers' incomes; (ii) Farmers Organization (FOs) are developing interesting strategies that combine private and public-type instruments, but these initiatives are being implemented on a very small scale, and are largely supported by donors and technical assistance providers; (iii) government can play a key role in their operations, often serving as the major trading 
The Nature of Food Commodity...

Nurliza

partner for their products. The current challenge is to develop a joint public-private partnership approach to agricultural development; (iv) improved market transparency and data availability to promote an efficient supply response in line with realistic expectations on the future evolution of supply-demand balances (Davis, 20I I).

The price spike was due to the speculative bubble could be taken to prevent for managing price volatility: (i) a first improvement could be simply to begin remedying the imbalance between certain important regulatory bodies and experts; (ii) combating 'large positions that lead to manipulation' irrespective of whether they are held by financial participants or not; (iii) regulatory bodies should carefully study and acquire expertise; (iv) access to derivatives markets could be restricted to traders and specialist brokers; (v) reduce the incentives for financial speculation; (vi) strengthening of spot markets may be brought about by investing in better warehousing facilities, communications services and in transport infrastructure; (vii) spot market regulation would be necessary in order to ensure that the delivery requirements do not result in hoarding (Schutter, 2010).

\section{The Relationship between Food Commodity Prices and The Inflation}

There are some of the criteria to determine the causality of food commodity prices, i.e. the level of consistency and mechanistic or define a lurking variable to explain their relationships (Juanda \& Junaidi, 20I2). However, the crucial issues of timeseries data behavior were the stationary or autocorrelation issues so that the stationary-test should be done. The stationary-test proved that most of the first lag data (D) were stationary in both of ADF-test and PP-test. Hereafter, the cointegration-test was used to determine the presence of long-term equilibrium relationship between food commodity prices and the inflation. The result proved that all of the food commodity prices and the inflation (food inflation and total inflation) were co-integrated or there were a long-term relationship (co-integration). In the short-run, maybe there was not equilibrium because of the desire of economic agent weren't consistent to the real event. Thus, adjustment or Error Correction Mechanism (ECM) was required to achieve equilibrium in the long-term.

The speed of adjustment can be define as the time elapsed between the move an initial set of macroeconomic variables to targeted set of such variables or refers to the time elapsed in moving from one organizational economic structure or another. 
The speed of adjustment also defined as the mean of the length of the time periods required for the transmission of the full effect of an exogenous shock from the independent to the dependent variable of the econometric model used in the analysis. The speed of adjustment refers to the total time required to move from one set of macroeconomic variables to another and to introduce economic reforms and make them operational (Nsouli et.al., 2002).

ECM models in Table I proved that the change of food inflation and total inflation due to the change of food commodity prices in the long-term was balanced by the error correction component in the pre-period. The changes in food commodity prices described the disturbance in the short-term, while the error correction component describes the adjustment towards long-term equilibrium. ECT (Error Correction Term) shown that their coefficient adjustment factors were statistically significant or short-term track deviation of commodity food prices will be adjusted again in the long-term track or equilibrium tracks by $(E C T * 100 \%)$ in the first period (month) and the rest in the next periods. While, the negative sign of lag ECT indicated that the correction or adjustment move towards the long-term equilibrium which was not in line with the inflation, and contrarily with the positive sign of the lag ECT that would steer the long-term equilibrium.

\section{Table I. Estimation of ECM}

\begin{tabular}{|c|c|c|c|c|c|}
\hline \multirow{2}{*}{ Food Prices } & \multirow{2}{*}{ Variable } & \multicolumn{2}{|c|}{ Food Inflation } & \multicolumn{2}{|c|}{ Total Inflation } \\
\hline & & Coeff. & t-statistic & Coeff. & t-statistic \\
\hline \multirow[t]{3}{*}{ Red onion } & $\mathrm{C}$ & -0.063864 & $(-0.17 \mid 622)$ & $-0.0 \mid 4473$ & $(-0.1 \mid 4033)$ \\
\hline & $\mathrm{D}($ Red onion) & $9.15 \mathrm{E}-05$ & $(0.992965)$ & 7.5 IE-05 & $(2397083)^{* *}$ \\
\hline & ECT $(-I)$ & -0.839805 & $(-6.494080) * * *$ & -1.040345 & $(-7.682073) * * *$ \\
\hline \multirow[t]{3}{*}{ Garlic } & C & $-0.06265 I$ & $(-0.166879)$ & -0.013259 & $(-0.100598)$ \\
\hline & $\mathrm{D}$ (Garlic) & $-3.63 \mathrm{E}-05$ & $(-0.263740)$ & $-2.20 \mathrm{E}-05$ & $(-0.456252)$ \\
\hline & ECT $(-1)$ & $-0.85 I 685$ & $-6.524507) * * * *$ & -1.056565 & $(-7.592623)^{* * * *}$ \\
\hline \multirow[t]{3}{*}{ Rice } & C & -0.119446 & $(-0.3 \mid 7824)$ & 0.002844 & $(0.02 \mid 203)$ \\
\hline & $\mathrm{D}$ (rice) & 0.000997 & $(0.718657)$ & -0.000278 & $(-0.550199)$ \\
\hline & ECT $(-I)$ & -0.884549 & $(-6.769292)^{* * * *}$ & -1.034550 & $(-7.28345 I)^{* * * *}$ \\
\hline Red pepper & C & -0.062248 & $(-0.165810)$ & -0.011534 & $(-0.087885)$ \\
\hline
\end{tabular}


The Nature of Food Commodity...

Nurliza

\begin{tabular}{|c|c|c|c|c|c|}
\hline \multirow{2}{*}{ Food Prices } & \multirow{2}{*}{ Variable } & \multicolumn{2}{|c|}{ Food Inflation } & \multicolumn{2}{|c|}{ Total Inflation } \\
\hline & & Coeff. & t-statistic & Coeff. & t-statistic \\
\hline & $\mathrm{D}$ (Red pepper) & $-1.22 \mathrm{E}-05$ & $(-0.379959)$ & $-2.92 \mathrm{E}-06$ & $(-0.258258)$ \\
\hline & ECT $(-I)$ & -0.848994 & $(-6.525065)^{* * * *}$ & -1.063494 & $(-7.633679) * * * *$ \\
\hline \multirow[t]{3}{*}{ Chicken meat } & C & $-0.06453 \mid$ & $(-0.172956)$ & -0.013963 & $(-0.107 / 94)$ \\
\hline & $\mathrm{D}$ (Chicken meat) & 0.000111 & $(1.122289)$ & 6.26E-05 & $(-18170 \mid 5)$ \\
\hline & ECT $(-1)$ & -0.860398 & $(-6.589373)^{* * * *}$ & -1.051216 & $(-7.587342)^{* * * *}$ \\
\hline \multirow[t]{3}{*}{ Beef } & C & -0.073640 & $(-0.197106)$ & -0.023404 & $(-0.177891)$ \\
\hline & $D($ Beef) & $-6.86 \mathrm{E}-06$ & $(-0.111032)$ & $1.86 \mathrm{E}-05$ & $(0.854327)$ \\
\hline & ECT $(-I)$ & $-0.88928 I$ & $(-6.7387 \mid 4)^{* * * *}$ & -1.067 .335 & $(-7.76095 I)^{* * * *}$ \\
\hline \multirow[t]{3}{*}{ Sugar } & C & -0.064494 & $(-0.172747)$ & -0.010677 & $(-0.081612)$ \\
\hline & $\mathrm{D}$ (Sugar) & 0.000498 & $(0.978706)$ & $-9.84 \mathrm{E}-05$ & $(-0.548265)$ \\
\hline & ECT $(-1)$ & -0.850544 & $(-6.570 \mid 94)^{* * * *}$ & -1.050024 & $(-7.55430 I)^{* * * *}$ \\
\hline \multirow[t]{3}{*}{ Corn } & C & -0.063069 & $(-0.170800)$ & -0.029487 & $(-0.222880)$ \\
\hline & $\mathrm{D}$ (Corn) & -0.000528 & $(-0.5 \mid 3860)$ & 0.000376 & $(-1016326)$ \\
\hline & ECT $(-I)$ & -0.922772 & $(-6.9287 \mid 4)^{* * * *}$ & -1.066695 & $(-7.69847 I)^{* * * *}$ \\
\hline \multirow[t]{3}{*}{ Peanuts } & C & -0.1111643 & $(-0.302753)$ & -0.037864 & $(-0.292004)$ \\
\hline & $\mathrm{D}$ (Peanuts) & 0.000432 & $(0.947506)$ & 0.000280 & -1.754 .094 \\
\hline & ECT $(-1)$ & -0.868550 & $(-6.649052)^{* * * *}$ & $-|.022 .55|$ & $(-7.500372) * * * *$ \\
\hline \multirow[t]{3}{*}{ Soybean } & C & -0.075663 & $(-0.202382)$ & 0.002060 & $(0.015684)$ \\
\hline & $\mathrm{D}$ (Soybean) & -0.000193 & $(-0.3054 \mid 3)$ & -0.000142 & $(-0.672103)$ \\
\hline & ECT $(-1)$ & -0.896736 & $(-6.323660)^{* * * *}$ & -1.033824 & $(-7.416406)^{* * * *}$ \\
\hline \multirow[t]{3}{*}{ Cooking oil } & C & -0.067498 & $(-0.181747)$ & -0.015693 & $(-0.120283)$ \\
\hline & D(Cooking oil) & 0.000108 & $(0.56 \mid 827)$ & 0.000115 & $(1.7 \mid I 529)^{*}$ \\
\hline & ECT $(-I)$ & -0.850730 & $(-6.520823) * * *$ & -1.030800 & $(-7.4789 \mid 2)^{* * *}$ \\
\hline \multirow[t]{3}{*}{ Eggs } & C & -0.064719 & $(-0.173917)$ & -0.019010 & $(-0.149056)$ \\
\hline & $D($ Eggs) & 0.000196 & $(0.948528)$ & 0.000165 & $(-2348.568)^{* * *}$ \\
\hline & ECT $(-I)$ & -0.835687 & $(-6.431349)^{* * * *}$ & -1.071582 & $(-7.874839) * * * *$ \\
\hline
\end{tabular}

Table I proved that the lag of ECT coefficient for all food commodity prices had statistically significant which mean the model of food inflation and total inflation was valid. Changes in food commodity prices are significant drived the inflation in the 
long-term although in the short-term insignificant. The lag of ECT coefficients had negative sign as expected; it indicated the convergence to equilibrium level in long-term. While, the highest of ECT coefficient lag to food inflation was corn, and followed by soybeans, beef, rice, peanuts, chicken meat, garlic, cooking oil, sugar, red, and red onion. On contrarily, the eggs have shown the smallest of ECT coefficient lag. Therefore, it's found evidence that changes in food commodity prices had significant influence for the inflation in the long-term, although in the short-term was insignificant or the fluctuation of short-term equilibrium will be corrected toward the long-term equilibrium. This result was also consistent with Zoli (2009), that the dynamic characteristics of commodity price spikes affect significantly the inflationary effect in the long-term; it is not just the level of prices reached in a 'spike' that matters but also the duration of the spike itself. For any given lag structure that determines the pass-through effect, the duration of the spike is a key determinant of the final effect on domestic food prices.

The sign of error correction term is negative as expected; it shown a convergence to equilibrium level in long-term. Significant error correction term indicates speed of adjustment to equilibrium level. These findings have been supported by empirical studies for recent years have that strong second-round effects of higher commodity prices on inflation have generally been absent in a majority of countries and that headline inflation has converged to core inflation (Cecchetti \& Moessner, 2008; Liu \& Weidner, 20I I).

Meanwhile, the highest of ECT coefficient lag related to total inflation was eggs, followed by beef, corn, red pepper, garlic, chicken meat, sugar, red onion, rice, soybeans, and cooking oil. Otherwise, peanuts had the smallest of ECT coefficient lag. Long-term track deviation of food commodity prices will be adjusted again in the longterm track was presented in Table 2. 
The Nature of Food Commodity...

Nurliza

Table 2. Adjustment Factors in the Long-term Equilibrium

\begin{tabular}{lcccc}
\hline \multirow{2}{*}{ Food Prices } & \multicolumn{2}{l}{ Food Inflation } & \multicolumn{2}{c}{ Total Inflation } \\
\cline { 2 - 5 } & $\%$ & days & $\%$ & days \\
\hline Red onion & $83.98 \%$ & 35.72 & $104.03 \%$ & 28.84 \\
Garlic & $85.17 \%$ & 35.22 & $105.66 \%$ & 28.39 \\
Rice & $88.45 \%$ & 33.92 & $103.46 \%$ & 29.00 \\
Red pepper & $84.90 \%$ & 35.34 & $106,35 \%$ & 28.21 \\
Chicken meat & $86.04 \%$ & 34.87 & $105,12 \%$ & 28.54 \\
Beef & $88.93 \%$ & 33.74 & $106,73 \%$ & 28.11 \\
Sugar & $85.05 \%$ & 35.27 & $105,00 \%$ & 28.57 \\
Corn & $\mathbf{9 2 . 2 8 \%}$ & 32.51 & $106,67 \%$ & 28.12 \\
Peanuts & $86.86 \%$ & 34.54 & $102,26 \%$ & 29.34 \\
Soybean & $89.67 \%$ & 33.45 & $103,38 \%$ & 29.02 \\
Cooking oil & $85.07 \%$ & 35.26 & $103,08 \%$ & 29.10 \\
Eggs & $83.57 \%$ & 35.90 & $107,16 \%$ & 28.00 \\
\hline
\end{tabular}

In Table 2, the relationship between food commodity prices and food inflation proved that the changes of corn price had the largest percentage or the shortest time of adjustment to move toward the long-term equilibrium. On the contrary, the changes of eggs price had the smallest percentage or the longest time of adjustments to move toward the long-term equilibrium. Meanwhile, the relationship between food commodity prices and total inflation proved that eggs price had the largest percentage or the shortest time of adjustment to move toward the long-term equilibrium. On the contrary, the changes of peanuts price had the smallest percentage or the longest time of adjustment to move toward the long-term equilibrium. Thus, the longest time of adjustment was related to food inflation was corn, Then, followed by soybeans, beef, rice, peanuts, chicken meat, garlic, cooking oil, sugar, red pepper, red onion, and eggs. While, the longest time of adjustment was related to total inflation was an egg, followed by beef, corn, red pepper, garlic, chicken meat, sugar, red onion, rice, soybeans, cooking oil, and peanuts. This result also proved that an increase in food inflation or total inflation due to changes in the price which had the shortest time of adjustment can be priority signal for the government to overcome the full transmission 
effect of an exogenous shock and to introduce economic reform through investment, infrastructure, and markets and make them operational.

The speed of adjustment relates to possible asymmetries in the response of prices to increases and decreases in inflation. Both phenomena are closely related to the structure of the market. The common assumption in economic writing is that the first-the length of the adjustment period-is negatively correlated to the degree of competition (i.e. the speed of adjustment is positively correlated to the competitiveness of the market), and that the second-the asymmetry of price responses-is an indication of the prevailing market structure (Lanza, I99I). Empirical studies also shown that the speed with which markets adjust to shocks is determined by actions of market agents who are involved in the transactions that link market levels; i.e., wholesalers, distributors, processors, retailing firms and the like (Vavra \& Goodwin, 2005). On the other hand, symmetric price adjustment has being noted to help optimize resource use; increase farm incomes; signal the degree of competitiveness, widen commodity markets and encourage value addition as well as create employment (Acquah \& Rebecca, (20I2); Akpan et.al, (20I6)).

The extensive literature on speed adjustment usually has been inconclusive and often conflicting in the policy advice it provides. A fairly clear-cut argument divides the proponents of a high speed of adjustment-what is often referred to as the shock, big bang-and those supporting a gradual approach. The debate centers on four major issues: the cost of adjustment, the credibility of the reform program, the feasibility of the approach, and the risks associated with the strategy (Nsouli et.al., 2002).

This finding was consistent with many we found in the literature that said that there was interrelations between the adjustment speed and business cycle variables. Most important, the speed of adjustment is higher when the term spread is higher, i.e., when economic prospects are good (Drobetz \& Wanzenried, 2006). Nevertheless, there is surprisingly little empirical evidence on the determinants of a time-varying adjustment speed, and especially about the influence of macroeconomic variables on the adjustment process. Altissimo et.al. (2005) stated that the most important reasons that prevent immediate price adjustment are: (i) long-run relationships with customers; (ii) explicit contracts which are costly to re-negotiate; and (iii) coordination problems arising from the fact that firms prefer not to change prices unless their competitors do 
The Nature of Food Commodity...

Nurliza

so. Thus, the properties of aggregate inflation that are eventually of interest for policy making, an important factor underlying the way inflation behaves over time are the features and determinants of the behavioral mechanisms underlying price setting.

The inflation behaves in a very persistent fashion; this result needs to be qualified substantially when looking at the current policy. Accordingly, the changes in regimes have brought about long-lasting changes in average inflation, which should not be mistaken for inflation persistence in response to other disturbances. This allows the policy makers to take a medium-term orientation as agents see through the temporary nature of various cost-push shocks. On the other hand, inflation expectation and inflation itself could become unanchored and costly to control when the series of costpush shock in one-direction risks increasing the perceived degree of persistence by the private sector. If communication by the government cannot alleviate this problem, it is advisable to respond quite aggressively and persistently to such shocks (Altissimo et.al., 2005).

Moreover, the large degree of uncertainty surrounding the estimates of inflation persistence, suggest that policy makers might want to be cautious and assume a relatively high degree of inflation persistence, resulting in a stronger response to inflationary disturbances rather than take the risk of assuming a too low degree of inflation persistence. This way, policy can insure against the risk that an initial shock is factored into the expectations of agents and will lead inflation to drift away at lower welfare cost. Clearly, the policy implications of the greater degree of price stickiness will depend on the source of the price stickiness. Some tentative implications can, however, be drawn: backward-looking rule-of-thumb behavior by a fraction of those firms; mark-up gap; continuous price adjustments; time-dependent price setting; sectoral heterogeneity; rule-of-thumb behavior and sticky information; the role of customer markets, coordination failures, and fair pricing (Angeloni et.al., 2006).

With prices being stickier, inflation will not respond to developments in marginal costs and/or the output gap to the same extent and at the same pace as in an economy with flexible prices. Accordingly, stabilizing inflation will be more costly in terms of output losses: for a targeted reduction in inflation, output needs to be reduced by more than in the case of flexible prices. Since inflation variability is more costly in such a case, monetary policy is well advised to put larger weights on reducing 
inflation variability relative to output variability. At the same time, a higher degree of price stickiness also reduces the impact of cost-push shocks on inflation (Altissimo et.al, 2005).

In an environment of rising commodity prices, the adoption of specific measures to stem inflationary pressure will depend on specific circumstances. The government could consider combining a broader range of policy instruments in responding to increasing food costs, which are a much heavier burden on most household budgets and create an understandably strong pressure for wage increases this calls for a combination policy measures. Thus, demonstrates the importance, from both a macroeconomic and social perspective, of new measures aimed at achieving greater commodity price stability and of quick-response instruments to mitigate the impact of sharp commodity price fluctuations (Davis, 20II).

The investment in the real economy can be support by the linkages and pursuing macroeconomic policies; enhance the linkages from commodity production with a view to create more symbiotic relationship between the development of manufacturing and commodities sectors. Production linkages have usually been seen as downstream linkages, but efforts towards enhanced growth and development through commodity processing and resource-based industrialization have mostly been unsuccessful. Tapping the potential for upstream linkages, i.e. the provision of inputs to commodity production, has recently been suggested as more promising. To the extent that transnational companies attempt to concentrate on their core competencies and search for suppliers of other inputs, taking advantage of local outsourcing opportunities could be a mutually beneficial area of cooperation between transnational enterprises on the one hand and local governments and enterprises on the other (Farooki \& Kaplinsky, 20I2).

In order to contribute to sustained development stability, a compensatory financing scheme that is more effective and administratively less cumbersome than previous schemes would certainly need to avoid procyclicality. One way of achieving this would be to include deferred repayment options in case of external shocks, including commodity price surges or collapses (Jacquet, 20II). In terms of eligibility principle, it should be sufficient that a country has no control over the cause of the shock that led to its need for compensatory financing. Then, foster the inclusiveness of 
The Nature of Food Commodity...

Nurliza

growth for commodities production and contribute to produce the economic growth, a fair sharing of resource rents between the state and investors. This solution would have the advantage to provie minimum standards towards a stable and certain environment for investors that would not easily be disrupted by perceived needs for renegotiations. Governments will need to find a balance between translating commodity revenues into higher productive investment and a better income distribution, on the one hand, and pursuing counter-cyclical policies, and therefore save part of the windfall as long as the terms of trade improve, on the others. The diversification and industrialization also remain the best means in the long run for countries to reduce their vulnerability to the adverse growth effects of commodity price volatility. This can be achieved best by integrating commodity policies into a country's overall development strategy (Davis, 20I I).

\section{CONCLUSION}

Beef was high volatility effects and indicated that suggesting domestic price refers to pricing phenomenon occurring when downstream prices react in a different manner to upstream price changes (vulnerable/have assymetric effect). While, soybeans, cooking oil, and food inflation indicated that suggesting domestic price are vulnerable but did not have volatility effects. The price of corn had volatility effect, but the time price change as the effects of myriad individual investors' decisions result in a pretty narrow range of change (normally distributed). However, the price of red onion, garlic, rice, red pepper, chicken meat, peanuts, eggs, total inflation did not have volatility effect and the time price change as the effects of myriad individual investors' decisions result in a pretty narrow range of change (normally distributed).

Meanwhile, changes in food commodity prices are significant drived the inflation in the long-term although in the short-term insignificant. The shortest time of adjustment can be priority signal for the government to overcome the full transmission effect of an exogenous shock and to introduce economic reform through investment, infrastructure, and markets and make them operational i.e. Corn and egg prices effect in food inflation; eggs and peanuts prices effect in total inflation. Strong second-round effects of higher commodity prices on inflation have generally been absent converged to core inflation. 
The policies suggestions can be drawn. First, backward-looking rule-of-thumb behavior by a fraction of those firms; mark-up gap; continuous price adjustments; timedependent price setting; sectoral heterogeneity; rule-of-thumb behavior and sticky information; the role of customer markets, coordination failures, and fair pricing. Second, monetary policy is well advised to put larger weights on reducing inflation variability relative to output variability. Third, the adoption of specific measures to stem inflationary pressure will depend on specific circumstances, from both a macroeconomic and social perspective to achieve price stability and of quick-response instruments to mitigate the impact of sharp commodity price fluctuations. Fourth, the investment in the real economy that can be support by the linkages and pursuing macroeconomic policies; enhance the linkages from commodity production with a view to create more symbiotic relationship between the development of manufacturing and commodities sectors. Fifth, compensatory financing scheme that is more effective and administratively less cumbersome than previous schemes would certainly need to avoid procyclicality. Sixth, foster the inclusiveness of growth for commodities production and contribute to produce the economic growth, a fair sharing of resource rents between the state and investors needs to be ensured. The diversification and industrialization also remain the best means in the long run for countries to reduce their vulnerability to the adverse growth effects of commodity price volatility.

\section{REFERENCES}

Acquah, H. D. \& O. Rebecca. (20I2). Spatial Market Integration and Price Transmission of Selected Plantain Markets in Ghana. Journal of Sustainable Development. Vol. 14: 208-217.

Akpan, S. B. et.al. (2016). Nature of Price Adjustment and Market Integration among Stages in Cassava Value Addition Chain in Southern Nigeria. Journal of Social Sciences. Vol. I2(I): 27.35.

Altissimo, F. et.al. (2005). Inflation Persistence and Price Setting Behaviour in the Euro Area. Frankfurt, Germany: European Central Bank (ECB).

Angeloni, I. et.al. (2006). New Evidence on Inflattion Persistence and Price Stickiness in The Euro Area: Implication for Macro Medellings. Journal of the European Economic Association. Vol. 4(2-3): 562-574. 
The Nature of Food Commodity...

Nurliza

Bakucs, Z. et.al. (20I4). Does Market Structure Influence Price Transmission in the Agro-food Sector? A Meta-analysis Perspective. Journal of Agricultural Economics. Vol. 65(I): I-25.

Blanchard, O. \& J. Gali. (2007). The Macroeconomic Effects of Oil Price Shocks: Why are they So Different from the 1970s? NBER Working Paper No. I3368.

Cecchetti, S \& R Moessner. (2008). Commodity prices and inflation dynamics. BIS Quarterly Review, December.

Davis, J. (20II). Agricultural price volatility and its impact on government and farmers: a few observations. OECD Agricultural Price Volatilities Conference: G20 Outreach, June I4-I5 (Pp. I-I7). Paris: UNCTAD.

Drobetz, W. \& G. Wanzenried. (2006). What Determines the Speed of Adjustment to the Target Capital Structure? Applied Financial Economics. Vol. I6(I3): 94 I-958.

Dwyer, A. et.al. (20II). Global Commodity Markets - Price Volatility and Financialisation. Bulletin of Reserve Bank of Australia. June Quarter 20 I I: 49-58.

Engle, R. (2002). New Frontiers for ARCH Models. Journal of Applied Econometrics. Vol. 17: 425-446.

EU-Commission. (2008). Is there a Speculative Bubble in Commodity Markets? Brussels: Commission Staff Working Document, Task force on the role of speculation in agricultural commodities price movements, SEC(2008)297I, 3, I.

Farooki, M. \& R. Kaplinsky. (20I2). The Impact of China on Global Commodity Prices: The Global Reshaping of The Resource Sector. New York: Routledge .

Ferrucci, G. et.al. (2012). Food Price Transmission in the Euro Area: The Role of Asymmetries and Non-Linearities. International Journal of Central Banking. Vol. 8: 179-217.

Hassan, S. A. \& H. Regassa. (20I2). Asymmetric Behavior of Volatility in Gasoline Prices Across Different Regions of the United States. Journal of Finance and Accountancy. Vol. 10: 1-9.

IMF. (2008). Is Inflation Back? Commodity Prices and Inflation, Chapter 3 World Economic Outlook. Washington: International Monetary Fund.

Jacks, D. S. et.al. (20II). Commodity Price Volatility and World Market Integration Since 1700. The Review of Economics and Statistics. Vol. 93(3): 800-8I3. 
Jacquet, P. (20I I). Improving risk management to cope with food price volatility and promote agricultural development: G20 mission on addressing the effects of price volatility, Interim recommendations. The National Food Security Mission (NFSM).

Juanda, B. \& Junaidi. (2012). Ekonometrika Deret Waktu: Teori dan Aplikasi. Bogor: IPB Press.

Keay, I. (20I0). The Impact of Commodity Price Volatility on Resource Intensive Economies. Ontario, Canada: Queen's Economics Department Working Paper No. 1274.

Lanza, A. (1991). Speed of Adjustment and Market Structure: A Study of the Gasoline Market in Germany. London: Oxford Institute for Energy Studies.

Liu, Z. \& J. Weidner (20II). Does Headline Ination Converge to Core?" FRBSF Economic Letter.

Meyer, J. \& S.V. Cramon-Taubadel. (2004). Asymmetric Price Transmission: A Survey. Journal of Agricultural Economics. Vol. 55: 58I-6I I.

Nsouli, S. M. et.al. (2002). The Speed of Adjustment and the Sequencing of Economic Reforms: Issues and Guidelines for Policymakers. IMF.

Peltzman, S. (2000). Prices Rise Faster than They Fall. Journal of Political Economy, 108, 466-502.

Pindyck, R. S. (2004). Volatility and Commodity Price Dynamics. The Journal of Futures Markets. 24(I I): 1029-1047.

Rayner, V., Laing, E., \& Hall, J. (20I I, March). Developments in. RBA Bulletin, I5-2I.

Regnard, N. \& J.M. Zakoïan. (20II). A Conditionally Heteroskedastic Model with Time-varying Coefficients for Daily Gas Spot Prices. Energy Economics. Vol. 33(6): |240-|25|.

Santoso, T. (20I I). Aplikasi Model GARCH Pada Data Inflasi Bahan Makanan Indonesia. Aset. Vol. 13 (I): 65-76.

Schutter, O. D. (2010). Food Commodities Speculation and Food Price Crises: Regulation to reduce the risks of price volatility. Briefing Note 02. United Nations Special Rapporteur on The Right to Food: I-I4.

Sholelah, F.H. (2016). Pengaruh Volatilitas Harga Terhadap Inflasi Bahan Makanan di Kota Malang. (Unpublished Thesis). Malang: Universitas Brawijaya.

Vavra, P. \& B.K. Goodwin. (2005). Analysis of Price Transmission along the Fod Chain. OECD Food, Agriculture and Fisheries Working Papers, No.3. 
The Nature of Food Commodity...

Nurliza

Von Braun, J. \& G. Tedesse. (20I2). Global Food Price Volatility and Spikes:An Overview of Costs, Causes, and Solutions. ZEF-Discussion Papers on Development Policy No. I6I. Bonn: The Center For evelopment Research (ZEF).

Zoli, E. (2009). Commodity Price Volatility, Cyclical Fluctuations, and Convergence: What is Ahead for Inflation in Emerging Europe? IMF Working Paper WP/09/4I. International Monetary Fund (IMF). 